\title{
Restricted feeding and human intestinal plasma cell development
}

\author{
W F KNOX \\ Department of Pathology, University of Manchester
}

SUMMARY Small intestinal mucosa from 129 necropsies and 15 surgical specimens from infants aged from birth to 21 months was examined for the presence.of cells containing IgA, IgM, and IgG using the PAP immunoperoxidase technique. Immunoglobulin containing cells were nearly always absent in infants under 1 week of age but occurred in the second week of life in infants who had had milk feeds. At this time, IgM containing cells were predominant, but IgA containing cells were more numerous by the sixth week. IgG containing cells were generally sparse. Parenterally fed infants who had received little or no intestinal milk showed significantly fewer immunoglobulin containing cells than those who had been fed normally, irrespective of gestation. Lack of stimulation by food and bacterial antigens may contribute to immunoglobulin containing cells failing to occur in these parenterally fed neonates.

Secretory immunoglobulins, principally IgA, play an important role in the defence of the intestinal tract against potential pathogens. ${ }^{1}$ Immunoglobulin producing cells are normally absent, however, from the intestinal mucosa at birth, although they have been observed in small numbers in a rectal biopsy specimen from a 12 day old infant. ${ }^{2} \operatorname{IgA}$ does not occur in appreciable amounts in saliva and nasopharyngeal secretions until 1-2 weeks of age. ${ }^{3}$ It is believed that the occurrence of plasma cells with production of immunoglobulin is stimulated by the arrival in the gut of bacterial and food antigens with the beginning of milk feeds. ${ }^{1}$ This response could be delayed by the immaturity of the intestine in infants born prematurely, or equally even a mature intestine could fail to produce immunoglobulin if oral feeds were replaced by parenteral nutrition. The present study was undertaken to assess the effects of premature birth and withholding of oral feeds on numbers of immunoglobulin producing cells observed in the lamina propria of the infant small intestine.

\section{Materials and methods}

Haematoxylin and eosin stained sections of small intestine from infant necropsies performed between 1976 and 1985 were examined, and 129 cases sufficiently well preserved to allow identification of cells in the lamina propria were selected. Roughly
$75 \%$ of sections examined from live born infants under a week old and $40 \%$ of those from infants aged over a week were considered suitable for inclusion. On the whole, intestine from infants aged over 3 months who had died suddenly at home showed the greatest autolysis. Tissue from 15 surgical intestinal resection and biopsy specimens was also included; this was histologically normal and obtained mainly from the margins of surgical resections for intestinal obstruction. The ages of the infants ranged from birth to 21 months, all but two being less than 1 year.

The series included both very sick infants who had undergone intensive care for days or weeks and previously healthy babies dying suddenly at home.

The material was fixed in $10 \%$ formalin and embedded in paraffin. Sections were stained for IgA, IgM, and IgG using the PAP immunoperoxidase technique ${ }^{4}$ after treatment with $0 \cdot 1 \%$ trypsin for 20 minutes. The presence or absence of immunoglobulin containing cells of each class was noted and $\operatorname{IgA}$ and IgM cells were counted using a modification of the method described by Skinner and Whitehead. ${ }^{5}$ Using an eyepiece grid and a X25 objective, the grid points falling on the lamina propria in any particular field were counted and the number of plasma cells in that field recorded. This was repeated over random mucosal fields until 1000 points had been counted (usually 20-25 fields), and the results were expressed as the number of im- 
munoglobulin containing cells per 1000 points of lamina propria. Although their presence was noted, IgG containing cells were not counted because of heavy staining of connective tissue, which tended to mask the positive cells.

\section{Results}

Table 1 shows the numbers of small intestinal specimens containing mucosal plasma cells at different postnatal ages. It is notable that of 54 infants aged 7 days or less, 53 had no mucosal plasma cells. The mean gestational age of this group was 32.5 weeks. Of those whose feeding state was known, only eight had been fed, while 35 had received no oral feeds. The remaining infant in this age group had been born at 30 weeks' gestation, was aged 6 days, and had not been fed. Very occasional IgM positive cells were seen in the lamina propria in this case.

Half of the infants aged 8-14 days had IgM containing cells in the lamina propria, but only $27 \%$ had $\operatorname{IgA}$ containing cells.

Table 2 shows details of the cases in this group. Four babies born at or near term, fed normally from birth and aged between 10 and 14 days, had IgM and IgA containing cells, with a preponderance of IgM cells. Three term infants who had received little or no enteral feeding showed rather fewer IgM cells, and only one had occasional $\operatorname{IgA}$ containing cells. The remaining 15 infants in this age group were born at less than 34 weeks' gestation and had received little or no enteral feeding. Occasional IgM containing cells were seen in four of these infants, but only one had $\operatorname{IgA}$ containing cells.

Those infants aged between 1 and 12 weeks were divided into two groups. 'Normal' feeders comprised those who had been fed either breast milk or formula by mouth or by tube from birth or for at least 14 days before death or operation. 'Restricted'

Table 1 Numbers of infants with lamina propria cells containing $\operatorname{Ig} M, \operatorname{Ig} A$, and IgG. Values are No (\%)

\begin{tabular}{|c|c|c|c|c|c|}
\hline \multirow{2}{*}{$\begin{array}{l}\text { Postnatal } \\
\text { age }\end{array}$} & \multirow{2}{*}{$\begin{array}{l}\text { No of } \\
\text { infants }\end{array}$} & \multicolumn{3}{|c|}{ Immunoglobulin cells } & \multirow[t]{2}{*}{ No cells } \\
\hline & & $I g M$ & $\operatorname{Ig} A$ & $\operatorname{Ig} G$ & \\
\hline \multicolumn{6}{|l|}{ Days: } \\
\hline $0-7$ & 54 & $1(2)$ & 0 & 0 & $53(98)$ \\
\hline $8-14$ & 22 & $11(50)$ & $6(27)$ & 7 (32) & $11(50)$ \\
\hline $15-21$ & 5 & 1 (20) & 0 & $1(20)$ & $3(60)$ \\
\hline $22-28$ & 7 & $7(100)$ & $7(100)$ & 4 (57) & $0(0)$ \\
\hline \multicolumn{6}{|l|}{ Weeks: } \\
\hline 4-6 & 12 & 7 (58) & $8(67)$ & 8 (67) & $3(25)$ \\
\hline $6-8$ & 11 & $10(91)$ & $11(100)$ & $11(100)$ & $0(0)$ \\
\hline $8-12$ & 16 & $15(94)$ & $15(94)$ & $10(63)$ & $1(6)$ \\
\hline Over 12 & 17 & 17 (100) & $17(100)$ & 17 (100) & $0(0)$ \\
\hline
\end{tabular}

Table 2 Numbers of IgM and IgA containing cells/1000 points of lamina propria in infants aged 8-14 days

\begin{tabular}{|c|c|c|c|c|c|}
\hline \multirow{2}{*}{$\begin{array}{l}\text { Gestation } \\
\text { (weeks) }\end{array}$} & \multirow{2}{*}{$\begin{array}{l}\text { Age } \\
\text { (days) }\end{array}$} & \multirow[t]{2}{*}{ Feeding } & \multicolumn{3}{|c|}{ No of cells/1000 points } \\
\hline & & & $\lg M$ & $\lg A$ & $\lg G$ \\
\hline 41 & 8 & 0 & 4 & - & + \\
\hline 40 & 12 & $\mathrm{~F}$ & 125 & 23 & + \\
\hline 40 & 12 & $\mathrm{~F}$ & 119 & 7 & + \\
\hline 40 & 13 & $\mathrm{~L}$ & 1 & 1 & + \\
\hline 40 & 14 & $\mathrm{~F}$ & 35 & 5 & - \\
\hline 40 & 14 & $\mathrm{~L}$ & 5 & - & + \\
\hline 38 & 10 & $\mathrm{~F}$ & 11 & 4 & - \\
\hline 33 & 8 & 0 & - & - & - \\
\hline 32 & 9 & 0 & - & - & - \\
\hline 32 & 10 & $\mathrm{~L}$ & - & - & - \\
\hline 32 & 10 & $\mathrm{~L}$ & - & - & - \\
\hline 31 & 9 & 0 & - & - & - \\
\hline 30 & 8 & 0 & - & - & - \\
\hline 30 & 10 & 0 & 1 & - & - \\
\hline 30 & 11 & 0 & - & - & - \\
\hline 30 & 13 & $\mathrm{~L}$ & - & - & - \\
\hline 30 & 13 & 0 & - & - & - \\
\hline 29 & 10 & 0 & 5 & 3 & - \\
\hline 27 & 10 & $\mathrm{~L}$ & - & - & - \\
\hline 27 & 12 & 0 & 4 & - & + \\
\hline 26 & 12 & 0 & - & - & - \\
\hline 25 & 14 & $\mathrm{~L}$ & 5 & - & + \\
\hline
\end{tabular}

Feeding: $F=$ full enteral feeding from birth; $L=$ feeds limited to one or two days only; $0=$ no enteral feeding.

feeders comprised those who had never been fed enterally or orally or who had been fed in this way for only short periods, usually only one or two days. These babies had been maintained on parenteral nutrition. Figure 1 shows the numbers of $\operatorname{IgA}$ and IgM containing cells in the 'normally' fed infants. It can be seen that in the second week of life IgM containing cells were more numerous, but that after the sixth week $\operatorname{IgA}$ containing cells were predominant. This predominance of IgA containing cells was also seen in those aged over 12 weeks (Table 3 ). Although IgG containing cells were not counted because of difficulties with heavy connective tissue staining that tended to obscure the cells, they were generally much fewer in number than either $\operatorname{IgA}$ or IgM producing cells.

The effect of feeding and of gestation, where known, on the numbers of IgA and IgM cells is shown in Figures 2 and 3. The number of immunoglobulin containing cells in the mucosa tended to remain low in infants who had not been fed enterally or orally compared with those who had received intestinal milk. Only two infants below 36 weeks' gestation had been fed 'normally'. Both were born at 34 weeks' gestation and survived for about three and a half weeks. Both had higher numbers of $\operatorname{IgA}$ and IgM containing cells than infants of a comparable age who had not been fed.

The remaining 31 babies below 36 weeks' gestation who had received little or no intestinal milk had 


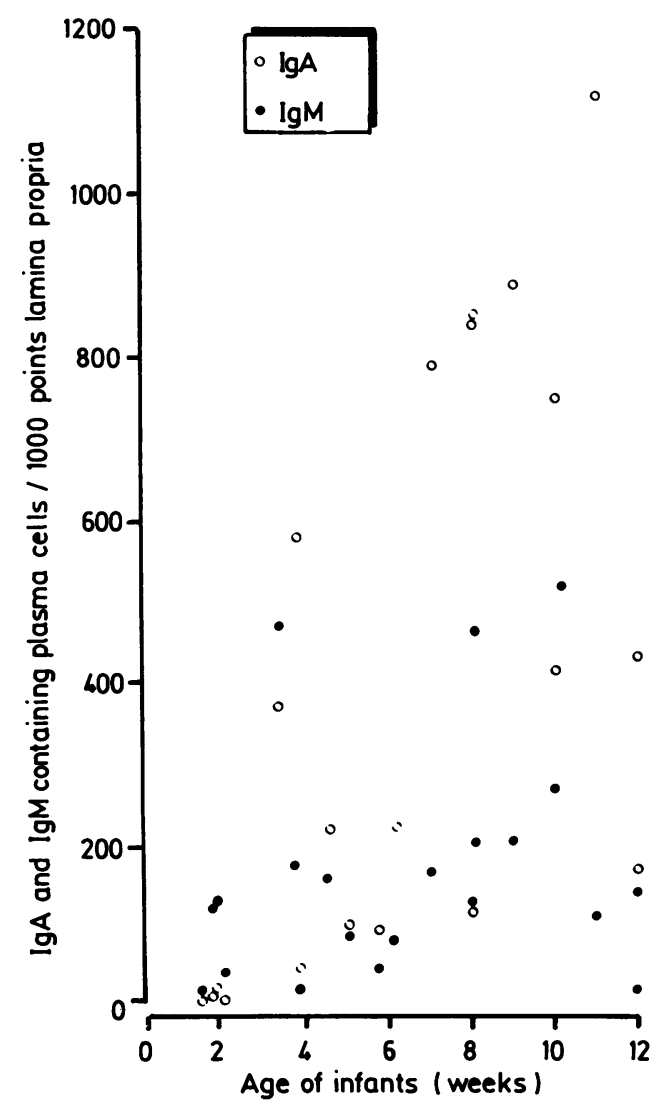

Fig. 1 Numbers of IgA and IgM containing plasma cells/1000 points of lamina propria in normally fed infants aged 1 to 12 weeks.

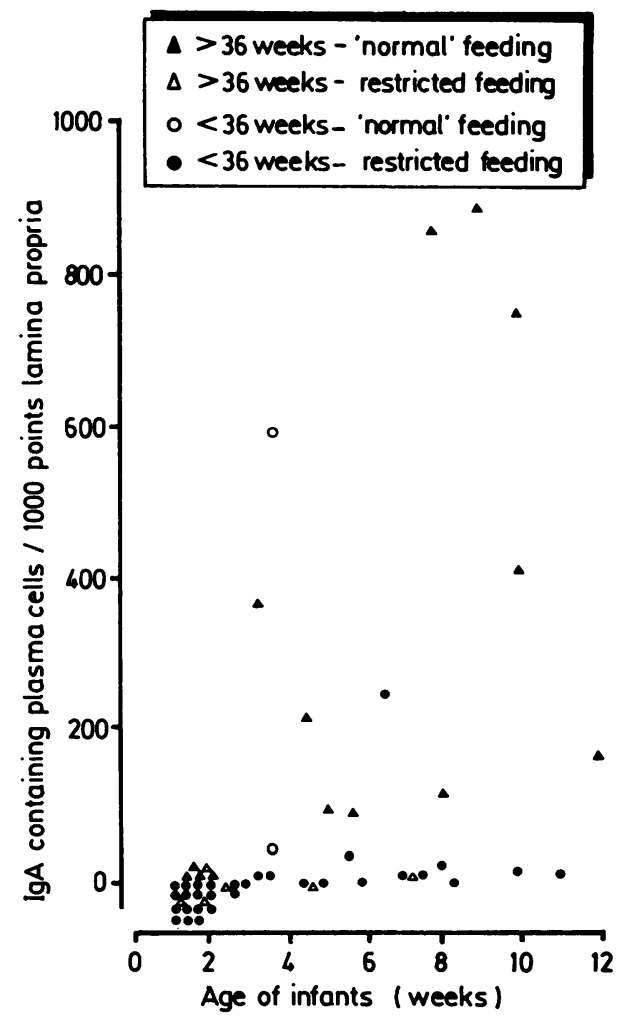

Fig. 2 Numbers of IgA containing cells/1000 points of lamina propria in infants receiving restricted enteral feeding compared with normally fed infants.

Table 3 Median and ranges of the numbers of $\operatorname{Ig} A$ and $\operatorname{IgM}$ cells/1000 points of lamina propria in groups with normal and restricted feeding

\begin{tabular}{|c|c|c|c|c|c|c|c|c|c|c|c|c|}
\hline \multirow{3}{*}{$\begin{array}{l}\text { Age } \\
\text { (gestation) }\end{array}$} & \multicolumn{6}{|l|}{$\operatorname{Ig} A$} & \multicolumn{6}{|l|}{$\lg M$} \\
\hline & \multicolumn{3}{|c|}{ Normal feeders } & \multicolumn{3}{|c|}{ Restricted feeders } & \multicolumn{3}{|c|}{ Normal feeders } & \multicolumn{3}{|c|}{ Restricted feeders } \\
\hline & No & Median & Range & No & Median & Range & No & Median & Range & No & Median & Range \\
\hline $\begin{array}{l}8-14 \text { days } \\
\text { (all) } \\
15-42 \text { days }\end{array}$ & 4 & 6 & 4-23* & 18 & 0 & $0-3$ & 4 & 77 & $11-125^{*}$ & 18 & 0 & $0-5$ \\
\hline $\begin{array}{l}\text { (all) } \\
\text { 6-12 weeks }\end{array}$ & 7 & 212 & $43-572^{*}$ & 11 & 0 & $0-33$ & 7 & 88 & $17-462^{*}$ & 11 & 0 & $0-5$ \\
\hline $\begin{array}{l}\text { (all) } \\
\text { Over } 12 \text { weeks }\end{array}$ & 10 & 766 & $113-1117^{*}$ & 9 & 7 & $0-240$ & 10 & 177 & $10-503^{*}$ & 9 & 10 & $0-80$ \\
\hline $\begin{array}{l}\text { (all) } \\
8 \text { days- } \\
12 \text { weeks } \\
(36 \text { weeks }+ \text { ) }\end{array}$ & 10 & 457 & $61-1260$ & 6 & 0 & $0-5$ & 10 & 265 & $40-606$ & 6 & 5 & $0-7$ \\
\hline
\end{tabular}

*p<0.002 by Mann-Whitney $U$ test. 


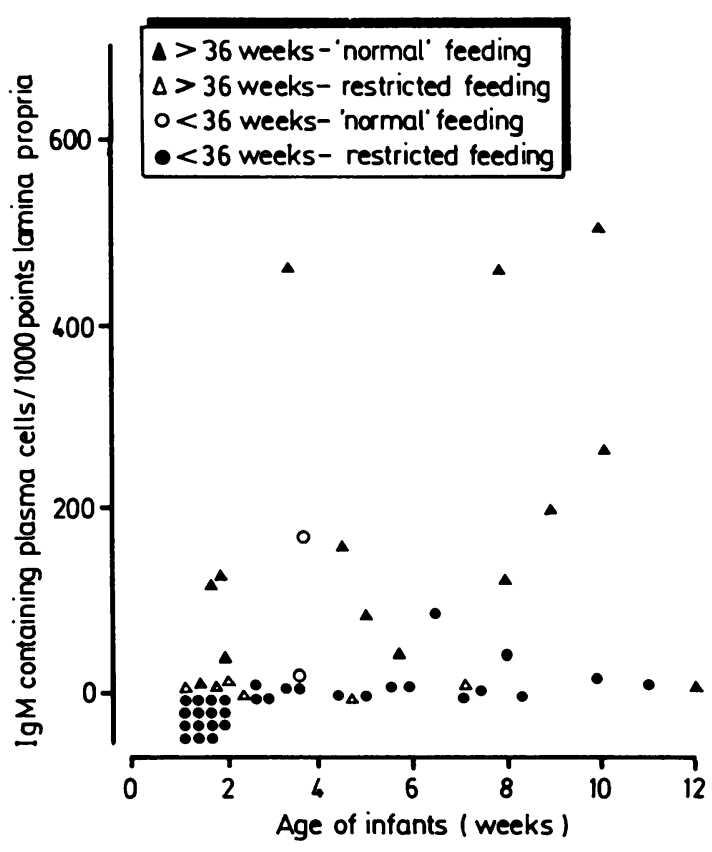

Fig. 3 Numbers of IgM containing cells/1000 points of lamina propria in infants receiving restricted enteral feeding compared with normally fed infants.

a mean gestational age of 29.8 weeks and included 14 infants born at less than 30 weeks' gestation. Thus it was not possible to separate the effects of intestinal immaturity and lack of normal feeding in these very small infants.

Overall, however, the differences in the numbers of cells between the 'normal' and 'restricted' feeders was significant (Table 3), as was the case for those infants born at or above 36 weeks' gestation.

The number of infants who were known to have been breast fed was too small to allow comparison between breast and bottle fed infants.

\section{Discussion}

A limitation of any histological study of the human neonatal small intestine is availability of tissue. Small intestinal biopsies are not commonly performed in the first weeks of life, and postmortem tissue invariably shows some autolysis. In every postmortem case included in this study it was possible to determine the presence or absence of mucosal immunoglobulin containing cells, even if meaningful counts were not feasible in a few instances. Because the material was obtained from the files, specimen orientation was not always ideal for quantitative studies and it was not always possible to determine the exact site in the small intestine from which the tissue had come.

A number of methods have been used for the quantitation of mucosal plasma cells, the results being expressed as cells per 1000 points of lamina propria, $\mathrm{mm}^{2}$ of mucosa, $\mathrm{mm}^{2}$ of lamina propria, or mucosal tissue unit. ${ }^{5-8}$ Each method has advantages and drawbacks. ${ }^{5}$ For the material used in this study, in which specimen orientation was often not ideal, estimation of the number of cells $/ 1000$ points of lamina propria was considered to be the most appropriate. The aim was not to establish absolute numbers of mucosal plasma cells of different immunoglobulin classes, but to allow comparisons between the cases in the study.

There have been few studies of the time of occurrence and numbers of small intestinal plasma cells in the very young human infant. Bridges $e t$ al found plasma cells in only one of 15 ileal and appendiceal specimens from children under 1 month of age. ${ }^{9}$ In the study by Perkkio and Savilahti no immunoglobulin containing cells were seen in intestinal specimens from nine infants aged less than 12 days, although a few IgA and IgM containing cells were present in a rectal biopsy specimen from a 12 day old baby. ${ }^{2}$ In rectal biopsy specimens the mean number of IgM containing cells exceeded that of IgA containing cells, but this was reversed in babies over a month. These observations are similar to those in this study in which immunoglobulin containing cells are absent or sparse before 2 weeks of age, with IgM cells predominating in the second week of life. IgA containing cells exceeded IgM containing cells, however, from the sixth week. Other workers have also noted the predominance of IgA containing cells in the infant gut, although they are comparatively less numerous in children less than 2 or 3 years of age than in older children. ${ }^{6} 810$

There have been conflicting reports on the time of occurrence and concentrations of $\operatorname{IgA}$ and other immunoglobulins in intestinal contents, saliva, and other secretions, differences in results probably reflecting varying methodology. Several workers have found no IgA in the saliva in the first week of life $;{ }^{311}$ it occurs from the second week onward and is present in most normal infants by 1 month of age. ${ }^{11}$ Roberts and Freed, however, using a sensitive radioimmunoassay, detected $\operatorname{IgA}$ in salivary and nasal secretions from the first day of life in both breast and bottle fed infants. ${ }^{12}$ Petit found $\operatorname{IgA}$ in fetal small intestine but not in neonatal meconium. ${ }^{13}$

This study has shown that the number of small intestinal mucosal immunoglobulin containing cells is considerably lower in one group of sick, often 
extremely premature infants who have received little or no food either by mouth or by tube than in often healthier infants who have been fed normally. Unfortunately, numbers are too low to separate the effects of low gestation and lack of feeding completely, only two infants born at less than 36 weeks' gestation, and aged at death between 1 and 12 weeks, having been fed normally.

In infants born at 36 weeks' gestation upwards, however, there is a considerable difference between those who have and have not been fed (Figs. 2 and 3).

Information on the effect of prematurity on the postnatal development of secretory immunity is sparse. Haworth et al found little difference between full term and premature infants in the development of salivary IgA, although IgA occurred in the serum at a slightly later age in preterm infants. ${ }^{3}$ Other workers have shown that gestational age and birth weight have little effect on concentrations of serum IgA. ${ }^{14-16}$ On the other hand, specific serum antibody production to food antigen such as bovine serum albumin seems to be impaired in premature infants. ${ }^{17}$

The state of nourishment of the infant may also affect numbers of $\operatorname{IgA}$ containing cells in the intestine. In children with protein energy malnutrition there is a pronounced decrease in the number of IgA containing cells in the lamina propria. ${ }^{18}$ In mice it was shown that only severe and prolonged malnutrition produced a reduction in gut $\operatorname{IgA}$ plasma cells. ${ }^{19}$

Continued antigenic stimulation, provided by food and bacterial growth, is probably necessary for the occurrence and maintenance of adequate numbers of mucosal plasma cells. It seems that antigen in the intestine stimulates B lymphocytes in the Peyer's patches. The stimulated $B$ lymphoblasts then migrate through the mesenteric lymph nodes and the thoracic duct to the blood stream and then home to the intestinal lamina propria and other glandular sites. A 'second signal' from antigen, $T$ cells, or mitogens stimulates final maturation to plasma cells. ${ }^{1}$ Wijesinha and Steer found that in patients who had undergone a defunctioning colostomy the number of $\operatorname{IgA}$ and $\operatorname{IgM}$ immunocytes was reduced in the defunctioned colon compared with the functioning segment. ${ }^{20}$ In mice Sagie et al found that cow's milk was a more potent stimulant of $\operatorname{IgA}$ plasma cell proliferation than a hydrolysed protein milk and concluded that there seemed to be a direct relation between the size and nature of antigenic stimuli in the intestine and development of IgA producing cells. ${ }^{21}$ It has been shown in rodents that exclusion of intestine from luminal antigenic stimulation by use of grafting or Thiry-Vella loops leads to a reduction in the concentration of plasma cells or specific antitoxin containing cells. ${ }^{22} 23$

The failure of development of adequate numbers of immunoglobulin containing cells in the cases of restricted enteral feeding in this study is likely to be due, at least in part, to lack of antigenic stimulation normally provided by food and concomitant growth of intestinal bacteria. The consequences of this are relevant to the modern intensive care units for the newborn where there is increasing survival of very premature sick infants unable to tolerate enteral feeding.

WFK is a Medical Research Council Research Training Fellow. I thank Dr A J Barson and Dr C J P Jones for their useful advice.

\section{References}

1 Hanson LA, Brandtzaeg P. The mucosal defence system. In: Stiehm ER, Fulginiti VA. Immunologic disorders in infants and children. Philadelphia: W B Saunders, 1980:137-64.

2 Perkkio M, Savilahti E. Time of appearance of immunoglobulincontaining cells in the mucosa of the neonatal intestine. Pediatr Res 1980;14:953-5.

3 Haworth JC, Dilling L. Concentration of gamma-A-globulin in serum, saliva and nasopharyngeal secretions of infants and children. J Lab Clin Med 1966;67:922-33.

4 Burns J. Background staining and sensitivity of the unlabelled antibody-enzyme (PAP) method. Comparison with the peroxidase labelled antibody sandwich method using formalin fixed paraffin embedded material. Histochemistry 1975;43:291-4.

5 Skinner JM, Whitehead R. Morphological methods in the study of the gut immune system in man. J Clin Pathol 1976;29:564-7.

6 Savilahti E. Immunoglobulin-containing cells in the intestinal mucosa and immunoglobulins in the intestinal juice in children. Clin Exp Immunol 1972;11:415-25.

${ }^{7}$ Binder V. Cell density in lamina propria of the colon: a quantitative method applied to normal subjects and ulcerative colitis patients. Scand J Gastroenterol 1970;5:485-90.

8 Brandtzaeg P, Baklien K. Immunoglobulin-producing cells in the intestine in health and disease. Clin Gastroenterol 1976;5:251-69.

9 Bridges RA, Condie RM, Zak SJ, Good RA. The morphologic basis of antibody formation development during the neonatal period. J Lab Clin Med 1959;53:331-56.

10 Maffei H, Kingston D, Hill I, Shiner M. Histopathologic changes and the immune response within the jejunal mucosa in infants and children. Pediatr Res 1979;13:733-6.

1 Selner JC, Merrill DA, Claman HN. Salivary immunoglobulin and albumin: development during the newborn period. $J$ Pediatr 1968;72:685-9.

12 Roberts SA, Freed DLJ. Neonatal IgA secretion enhanced by breast feeding. Lancet 1977;ii:1131.

13 Petit J, Galinha A, Salomon J. Immunoglobulins in the intestinal content of the human fetus with special reference to IgA. Eur J Immunol 1973;3:373-5.

14 Berg T. Immunoglobulin levels in infants with low birth weights. Acta Paediatr Scand 1968;57:369-76.

15 Rothberg RM. Immunoglobulin and specific antibody synthesis during the first weeks of life of premature infants. $J$ Pediatr 1969;75:391-9.

16 Conway SP, Dear PRF, Smith I. Immunoglobulin profile of the preterm baby. Arch Dis Child 1985;60:208-12.

17 Rieger CHL, Rothberg RM. Development of the capacity to produce specific antibody to an ingested food antigen in the premature infant. J Pediatr 1975;87:515-8. 
18 Green F, Heyworth B. Immunoglobulin-containing cells in jejunal mucosa of children with protein-energy malnutrition and gastroenteritis. Arch Dis Child 1980;55:380-3.

19 Wade S, Lemonnier D, Alexiu A, Bocquet L. Effect of early postnatal under- and over- nutrition on the development of $\operatorname{IgA}$ plasma cells in mouse gut. J Nutr 1982;112:1047-51.

20 Wijesinha SS, Steer HW. Studies of the immunoglobulinproducing cells of the human intestine: the defunctioned bowel. Gut 1982;23:211-4.

21 Sagie E, Tarabulus J, Maier DM, Freier S. Diet and development of intestinal IgA in the mouse. Isr J Med Sci 1974;10: 532-4.
22 Ferguson A, Parrott DMV. The effect of antigen deprivation on thymus-dependent and thymus-independent lymphocytes in the small intestine of the mouse. Clin Exp Immunol 1972;12:477-88.

23 Husband AJ, Gowans JL. The origin and antigen-dependent distribution of IgA-containing cells in the intestine. $J$ Exp Med 1978;148:1146-60.

Correspondence to Dr W F Knox. Department of Pathology, University of Manchester, Stopford Building, Oxford Road, Manchester M13 9PT, England.

Received 29 April 1986

\section{Twenty five years ago}

\section{Primary myocardial disease in infancy: clinical aspects}

\section{John Apley (Bristol)-Arch Dis Child 1961;36:366-372}

'Primary myocardial disease is a clinical group of disorders with some features in common, in which the heart is mainly affected with cardiomegaly and with suggestive or characteristic electrocardiographic findings. It is clear that the boundaries of the group will change as more is learnt of aetiology and pathology.' The inclusion of cases is rather arbitrary, as pointed out by Dr Apley, and the diagnosis of primary myocardial disease embraces anomalous left coronary artery, glycogen storage disease of the heart, calcification of the coronary arteries, endocardial fibroelastosis, and possibly virus myocarditis.

'All the patients were under 1 year of age when first seen. A family history of a similar disorder is sometimes obtained and the patient's history is of a persistent or episodic disorder beginning at 2 or 3 months of age or even earlier. Laboured breathing, wheeziness, 'chestiness' or lung infections, sometimes with slight cyanotic episodes occur. Three quarters of all children were in heart failure when first examined, and slight to marked cyanosis was observed in half the infants with heart failure. The heart was always enlarged. The E.C.G. changes of left ventricular strain are important in diagnosis. Characteristically, the S-T level is depressed or elevated. The T wave tends to be small, isoelectric or inverted, especially in leads $1, V_{5}$, and $V_{6}$ with a horizontal heart, or in leads II, III, $V_{5}$, and $V_{6}$ with a vertical heart. In addition there is usually a tall upright QRS indicative of ventricular hypertrophy, and often exaggeration of $P$ waves which suggest auricular enlargement. In most cases of aberrant left coronary artery the E.C.G. is similar to that of anterior myocardial infarction in the adult. Among those children with myocarditis and endocardial fibrosis treatment with digitalis, and oxygen and antibiotics in addition, may result in survival and full recovery.'

(Dr John Apley may be best known for his contributions to psychosomatic disorders in childhood, but he was very much the 'complete paediatrician', inevitably becoming rarer in this age of increased specialisation. His writings cover so much of paediatrics, and he certainly gave the enviable impression that communication, spoken and written, came more easily to him than to most others. NEIL GORDON.) 